\title{
Characterization of Curcuminoid from Curcuma xanthorrhiza and Its Activity Test as Antioxidant and Antibacterial
}

\author{
Sri Atun", Nurfina Aznam', Retno Arianingrum', Senam', Bian Ihda An Naila', Astuti Lestari', \\ Nur Aini Purnamaningsih ${ }^{2}$
}
'Department Chemistry Education, Faculty of Mathematics and Natural Science, Universitas Negeri
Yogyakarta, Jl. Colombo No. 1 Depok, Sleman, Yogyakarta, 55281, Indonesia
${ }^{2}$ Faculty of Health, Universitas Jendral Ahmad Yani, Jl. Brawijaya, Ringroad Barat, Ambarketawang, Gamping, Sleman, Yogyakarta, 55294, Indonesia

*Corresponding author email: sriatun@uny.ac.id

Received June 25, 2019; Accepted July 02, 2020; Available online July 27, 2020

\begin{abstract}
Curcuminoids are the main component found in many Zingiberaceae family plants. The aim of this study was to characterize curcuminoid and its activity test as an antioxidant and antibacterial. Dryed powder of C. xanthorrhiza (1 kg) was macerated with ethanol for 24 hours at room temperature. Ethanol extract of $C$. xanthorrhiza was subsequently fractionated with $n$-hexane and chloroform to take the yellow or orange indicated contain of curcuminoids. Analysis of total phenolic levels was carried out by the Follin-Ciaocalteau method. The isolation of curcuminoid componens from this fraction was carried out by chromatographic method and the structure elucidation was performed by interpretation of spectroscopic data, including UV, IR, ${ }^{1} \mathrm{H}$ and ${ }^{13} \mathrm{C}$ NMR $1 \mathrm{D}$ and 2D. The antioxidant activity test used the DPPH (2,2-diphenylpicrylhydrazyl) method, while the antibacterial activity test used Kirby Baver test diffusion method. The results showed that the curcuminoid fraction yield was $10.06 \%$ from ethanol extract C. xanthorrhiza. The total phenolic content of curcuminoids fraction was $745.45 \pm 18.5 \mathrm{mg}$ galic acid (GA)/g extract. Curcuminoids fraction was isolated a known compound desmethoxycurcumin (1). The content of demethoxycurcumin (1) in curcuminoid fraction is $20.97 \%$. The antioxidant activity of curcuminoids fraction showed strongest activity with IC $5024.98 \mu \mathrm{g} / \mathrm{ml}$. Antibacterial activity against of the four pathogenic bacteria showed medium activity. The study suggests that curcuminoids extract from C. xanthorrhiza rhizome have potential compounds could be suitable for antioxidant and the treatment of various infections caused of microbial.
\end{abstract}

Keyword: antibacterial; antioxidant; Curcuminoids; Curcuma xanthorhiza; phenolic content

\section{INTRODUCTION}

Since ancient times in various parts of the world, many have used medicinal plants in traditional medicine to treat various types of diseases. Until now the products of several plants derived from fungi, bacteria, and other organisms continue to be used either as a pure mixture or as an extract. The Zingiberaceae plant family is spread across South and Southeast Asia, which consists of 47 genera and around 1000 species (Cronquist, 1981). Some species of this family are widely used in traditional herbs and various dishes. The Zingiberaceae family rhizome is widely used to treat diseases, such as fever, diarrhea, irregular menstruation, tuberculosis, inflammation of the gums, skin diseases, inflammation of the liver, tumors, and malaria (Heyne, 1987). Temulawak (Curcuma xanthorrhiza Roxb) is a species of plant native to Indonesia Zingiberaceae.

Several studies have been carried out on rhizome of C. domestica, C. longa, C.xanthorrhiza, and C. zedoaria shows the presence of curcumin derivatives and sesquiterpen compounds (Cucuzza, Motta,
Miretti, Accornero, \& Baratta, 2008). Curcuminoids contained in several species depending on the type of species. Some curcuminoid compounds that have been found in C. domestica and C. longa include curcumin, demethoxycurcumin, 1,7-bis (4-hydroxy-3methoxyphenyl)-1, 4, 6-heptatrien-3-on, 1-hydroxy1,7-bis(4-hydroxy-3-methoxy-diphenyl)-6-hepten-

3,5-dion, 1,7-bis(4-hydroxyphe-nyl)-1-hepten, 3,5dion, 1,7-bis (4-hy-droxyphenyl)-1,4,6-heptatrien-3on, and calebin A. Curcuminoid from C. xanthorrhiza contains curcumin and demethoxycurcumin (Lechtenberg, Quandt, \&Nahrstedt, 2004). Several studies on the pharmacological effects of curcuminoid compounds show antioxidant, anti-inflammatory, anti-cancer, antiviral, and antihepatotoxic activity (Itokawa, Qian, Akiyama, Susan, \& Lee, 2008; Wrigh, 2013; Nurfina \& Atun, 2016; Amalrai, Pius, Gopi, \& Gopi, 2017).

Research has further highlighted that curcumin possesses a synergistic effect with important antibiotics such as cefixime, vancomycin and tetracycline against Staphylococcus aureus (Mun, et al, 2013). In-vivo tests 
using animals indicate that curcumin used in high doses has strong antibacterial activity (Gunes, Gulen, Mutlu, Gumus, Tas, \& Topkaya, 2016). The aim of this study was to characterize curcuminoid fraction and its activity test as an antioxidant and antibacterial.

\section{EXPERIMENTAL SECTION \\ Apparatus and reagents}

Evaporator Buchi Rotavapor R-114, UV and IR spectra were measured with Varian Cary 100 Conc and Shimadzu 8300 FTIR, respectively. ${ }^{1} \mathrm{H}$ and ${ }^{13} \mathrm{C}$ NMR spectra were recorded with Jeol JNM A-5000 spectrometers, operating at $600.0 \mathrm{MHz}\left({ }^{1} \mathrm{H}\right)$ and 150.0 MHz $\left({ }^{13} \mathrm{C}\right)$ using residual and deuterated solvent peaks as internal standards, Vacuum liquid chromatography (VLC) was carried out using Si-gel Merck 60 GF254 (230-400 mesh), column chromatography using Si-gel Merck 60 (200-400 mesh) and TLC analysis on precoated Si gel plates Sigel Merck Kieselgel 60 F254 0.25 mm, 20 × 20 cm, spectronic 20, TLC scanner, incubator, autoclave, LAF (Laminatory Air Flow), coloni counter, forceps, micro pipettes, shaker, water bath, deep freezer, ruler (millimeter scale), petri plate, and analytical balance were used in this work. Dryed powder of Curcuma xanthorrhiza Roxb, ethanol, methanol, ethyl acetate, n-hexane, chloroform, 2,2-diphenyl-1-picrylhydrazyl (DPPH, Aldrich), ascorbic acid (Aldrich), folin-ciocalteu phenol reagent, sodium carbonate, gallic acid (Sigma), aluminum nitrate, potassium acetate, chloramphenicol, Mueller-Hinton agar (MHA, OXOID, Basingstoke, UK), Nutrient Broth (NB), Nutrient Agar (NA), paperdisk, DMSO (dimethyl sulfoxide), plastic wrap, aluminium foil, and aquadest were used in this work without further purification.

\section{Microorganism}

This study were used four pathogenic bacterial isolates of Escherichia coli ATCC 11229, Staphylococcus aureus ATCC25923, Staphylococcus epidermidis FNCC 0048, Streptococcus mutans were obtained from the Microbiology aboratory, Deparment Biology education, Faculty Mathematics and Natural Science, Universitas Negeri Yogyakarta, Indonesia. The microorganism were sub cultured and stored in a semisolid medium (Mueller Hinton agar plates) at $4^{\circ} \mathrm{C}$ until needed.

\section{Extraction of curcuminoid from ethanol extract of $C$. xanthorrhiza rhizome}

Dry powder of C. xanthorrhiza $(1 \mathrm{~kg})$ rhizome was macerated with ethanol for 24 hours at room temperature. The filtrate is separated and the residue is macerated again three times. The filtrate obtained was collected and concentrated using a vacuum evaporator, so that the concentrated extract was obtained. The concentrated ethanol extract of $C$. xanthorrhiza was further fractionated with $n$-hexane to remove the essential oil content and other lipid and non-polar components. Then the extract was partitioned with chloroform to take the dissolved fraction three times. The chloroform fraction was then dried under vacuum to produce an orange-yellow solid, and was used for further research. From previous studies, the chloroform fraction contained many component of the curcuminoids compound.

\section{Determination of total phenolic content}

Total phenolic content was determined using folinciocalteau reagent (Hagerman A, Harvey MI, Makkar AH, Mueller IH, Makar HPS, 2000). The curcuminoid extract $(1 \mu \mathrm{g} / \mathrm{mL})$, taken $200 \mu \mathrm{L}$, three replications) was mixed with folin-ciocalteu reagent $(0.4 \mathrm{~mL})$, water $(4 \mathrm{~mL})$ and sodium carbonate $(15 \% \mathrm{~b} / \mathrm{v}, 2 \mathrm{~mL})$ and absorbance at $760 \mathrm{~nm}$ it was measured after incubation at $50{ }^{\circ} \mathrm{C}$ for 10 minutes. As a standard phenol compound in this study using gallic acid (GA) at various concentrations $(50-200 \mu \mathrm{g} / \mathrm{mL})$. Total phenol content is expressed as $\mathrm{mg} \mathrm{GA} / \mathrm{g}$ extract.

\section{Isolation component of chloroform fraction from ethanol extract of $C$. xanthorhiza rhizome}

The isolation component of chloroform fraction from ethanol extract $C$. xanthorrhiza was done by using the chromatographic method. A portion $(50 \mathrm{~g})$ of the total chloroform fraction was fractionated by vacuum liquid chromatography (VLC) using a mixture of $n$-hexan- ethyl acetate solvent in in a variation ratio. The main fraction obtained is then separated and further purified using chromatography with various elvents repeatedly until a fraction showing a single stain is obtained. The obtained isolate was then dried as much as $70 \mathrm{mg}$, yellow orange. Furthermore, isolates were analyzed by UV-VIS, IR, NMR spectroscopy one and two dimensions. The isolated compound is a major component of the chloroform fraction and is used as a standard for the qualitative and quantitative analysis of the chloroform fraction. Quantitative analysis componen of fraction chloroform fram extract C. xanthorrhiza was carried out using TLC Scanner.

\section{Determination of antioxidant activity using the DPPH method}

The antioxidant activity test uses 2,2-diphenyl-1picrylhydrazin (DPPH) reagents as a radical source (Hanumantharaju, Shashidhara, Rajasekharan, \& Rajendra, 2010). Samples are dissolved in ethanol at various concentrations (1000-10 $\mu \mathrm{g} / \mathrm{mL}$ ). A total of 5 $\mathrm{ml}$ of sample was mixed with $5 \mathrm{ml}$ of DPPH solution in ethanol $(0.12 \mathrm{mM})$ placed in a dark room at room temperature for 30 minutes. The sample absorption activity was measured using spectronic 20 (Genesys) at a wavelength of $516 \mathrm{~nm}$ and compared with absorption of the blank solution. Percentage inhibition was calculated using the formula (\%) inhibition $=[(\mathrm{A}$ control - A sample)/ A control] x 100. The percent inhibition of each sample at various concentrations was used to calculate the $\mathrm{IC}_{50}$ of each sample. As a positive control in testing, ascorbic acid was used. 


\section{Determination of activity as antibacterial}

Antibacterial activity test was carried out in vitro by Kirby-Baver disc diffusion method with slight modifications (Bishnu, 2015). This experiment used four pathogenic bacterial cultures, namely Staphylococcus aureus ATCC 25923, Escherichia coli ATCC 11229, Streptococcus mutans, and Staphylococcus epidermidis FNCC 0048. The bacteria used in this study were cultured and stored in semisolid media (Mueller Hinton agar plate) at $4^{\circ} \mathrm{C}$ until needed. As a positive control chloramphenicol which is an antibacterial compound that has been widely used, while as a negative control DMSO $10 \%$ is also used as a sample solvent. Bacterial cultures were inoculated onto Muller Hinton agar plates and flattened with spatula drigalski. Paper disks are immersed in the solution of each sample at various concentrations $(0.01 ; 0.1 ; 0.5$ and $1.0 \% \mathrm{~b} / \mathrm{v})$ for five minutes. Then, paper discs are placed on the agar medium and incubated at temperature $37^{\circ} \mathrm{C}$ for 12 hours After 12 hours of incubation, the inhibition zone around paper discs was measured on a millimeter scale, this experiment was carried out three times.

\section{RESULTS AND DISCUSSION}

Curcuminoids extraction was carried out by maceration C. xanthorhiza rhizome powder using ethanol solvent. The content of essential oils, lipid components, and other non-polar compounds is removed by the addition of $n$-hexane. Furthermore, the ethanol extract is partitioned again with chloroform. The soluble chloroform fraction was dried under vacuum to obtain yelow-orange solid as much as $106 \mathrm{~g}(10.6 \%)$ (Figure 1).

Total phenolic content was determined using folinciocalteau reagent. Total phenol levels were expressed as mg Gallic Acid (GA)/g samples. Absorbance data and gallic acid concentration then made a regression curve and obtained a graph and regression equation obtained was $Y=0.0046 \mathrm{X}-0.0329$, with $r^{2}=$ 0.9851 . The results of calculating the total phenolic content in chloroform fraction can then be calculated by the formula, TPC $=\mathrm{C} \times \vee \times \mathrm{fp} \mathrm{mg} / \mathrm{g}$ extract (TPC $=$ total phenolic content; $C=$ concentration gallic acid from calibration curve data; $V=$ total volume; $f p=$ dilution factor), so that $745.45 \pm 18.5 \mathrm{mg} \mathrm{GA} / \mathrm{g}$ of chloroform fraction were obtained.

Isolation of the components of the chloroform fraction by chromatography obtained a major component of $70 \mathrm{mg}$, orange yellow (isolat 1). UV spectrum data of isolate 1 showed the presence of two maximum peak wavelengths at 203 and $418 \mathrm{~nm}$, which indicated the presence of a conjugated chromophore group that it approached the visible spectrum. IR spectrum data shows the presence of a hydroxy group at $3440 \mathrm{~cm}^{-1}$, the presence of $\mathrm{C}=\mathrm{O}$ in the area of $1628 \mathrm{~cm}^{-1}$ and the peaks of $\mathrm{C}=\mathrm{C}$ aromatic in the area of $1600-1500 \mathrm{~cm}^{-1}$. The IR spectrum data indicate that the compound contains a carbonyl group conjugated with an aromatic ring. UV and IR spectrum of isolate 1 are shown in figure 2 and 3.

The NMR ( ${ }^{1} \mathrm{H}$ and ${ }^{13} \mathrm{C}$ NMR) spectrum of isolate 1 are shown in Figures 4 and 5 . The ${ }^{13} \mathrm{C}$ NMR spectrum shows the presence of two carbonyl carbons at $\delta$ 183.5 and $183.46 \mathrm{ppm}, 12$ aromatic carbon at pada $127.8,123.1,115.04,148.07 ; 146.9 ; 109.8$ ppm (C5; C6; C7; C8; C9; C10) and $8127.84 ; 130.18$; $115.04 ; 158.13 ; 115.04$; and 130.18 ppm (C5 '; C6'; $\mathrm{C7}$ '; C8'; C9 '; C10'), four alkene carbons at $\delta 121.46$ and $140.49 \mathrm{ppm}(\mathrm{C} 3 ; \mathrm{C} 4)$ and $\delta 121.48$ and 140.83 ppm (C3 '; C4')), one methylene carbon at $\delta 29.86$ ppm (C2), and one methoxyl carbon at $\delta 56.14 \mathrm{ppm}$. The data shows that isolate 1 contained two carbonyl groups, two benzene rings, two pairs of carbon alkenes, one methylene carbon, and one methoxyl group. Furthermore, the ${ }^{1} \mathrm{H}$ NMR spectrum data showed two methylene protons at $\delta 1.27 \mathrm{ppm}$, two pairs of proton alkenes with trans configurations at $\delta$ 486.48 and 7.59 ppm; and $\delta 6.49$ and 7.57 ppm; three aromatic proton coupling ortho and meta at $\delta$ $7.11 ; 6.93$ and 7.03 ppm; two pairs of aromatic proton ortho couplings at $\delta 447.44(2 \mathrm{H})$ and 6.85 (2H) ppm; three methoxyl protons at $\delta 3.95 \mathrm{ppm}$. Two hydroxyl protons in the aromatic ring were not detected, but can be known from the oxyaryl carbon data at $\delta 148.7$ and $158.13 \mathrm{ppm}$. Furthermore, the data was further confirmed using a two-dimensional NMR consisting of HMQC and $H M B C$, which is complete in Table 1.

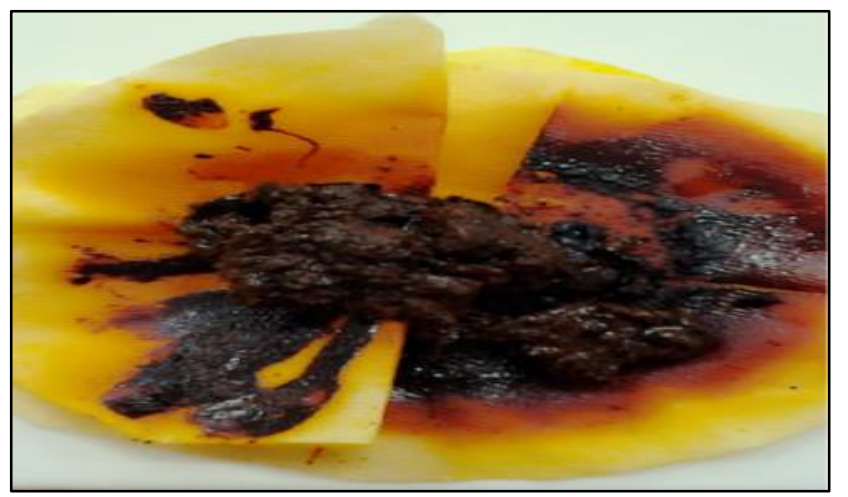

Figure 1. Chloroform fraction from C. xanthorrhiza rhizome 


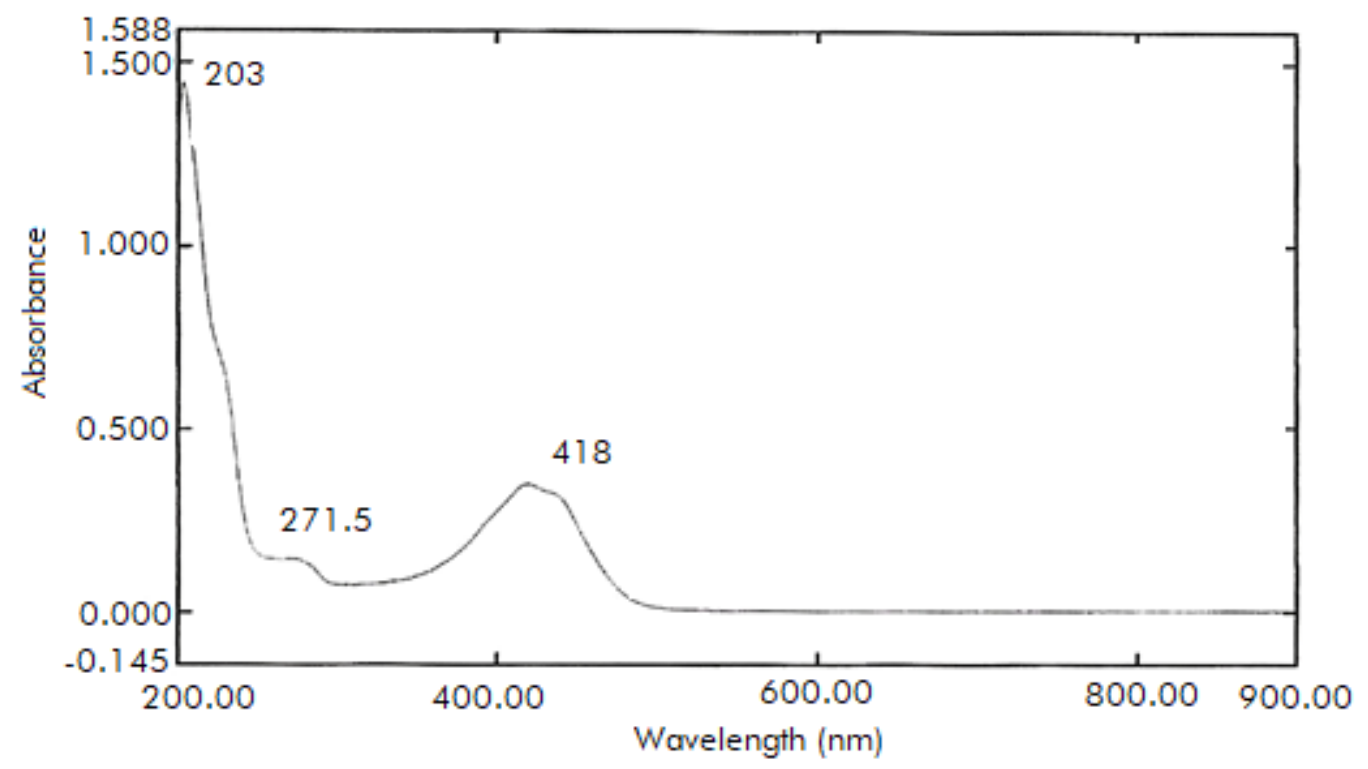

Figure 2. UV spectrum of compound isolate 1 (in methanol) from chloroform fraction of $C$. Xanthorrhiza

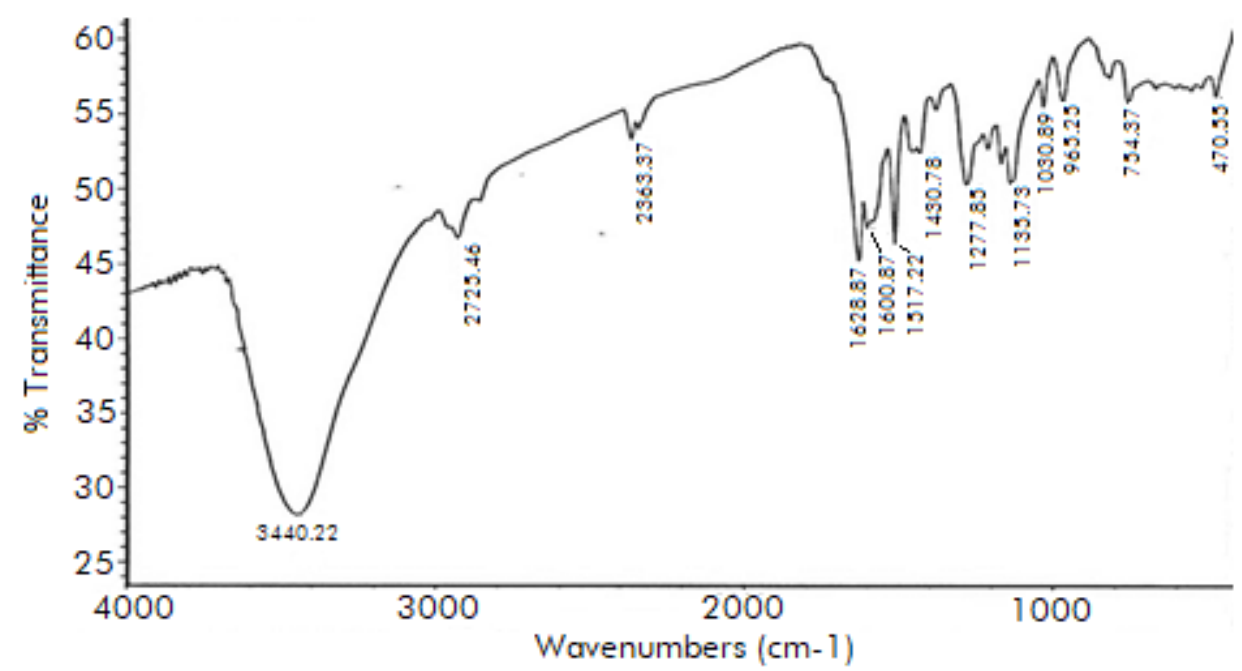

Figure 3. IR spectrum of compound isolate 1 (in $\mathrm{KBr}$ pellet) from chloroform fraction of $\mathrm{C}$. xanthorrhiza

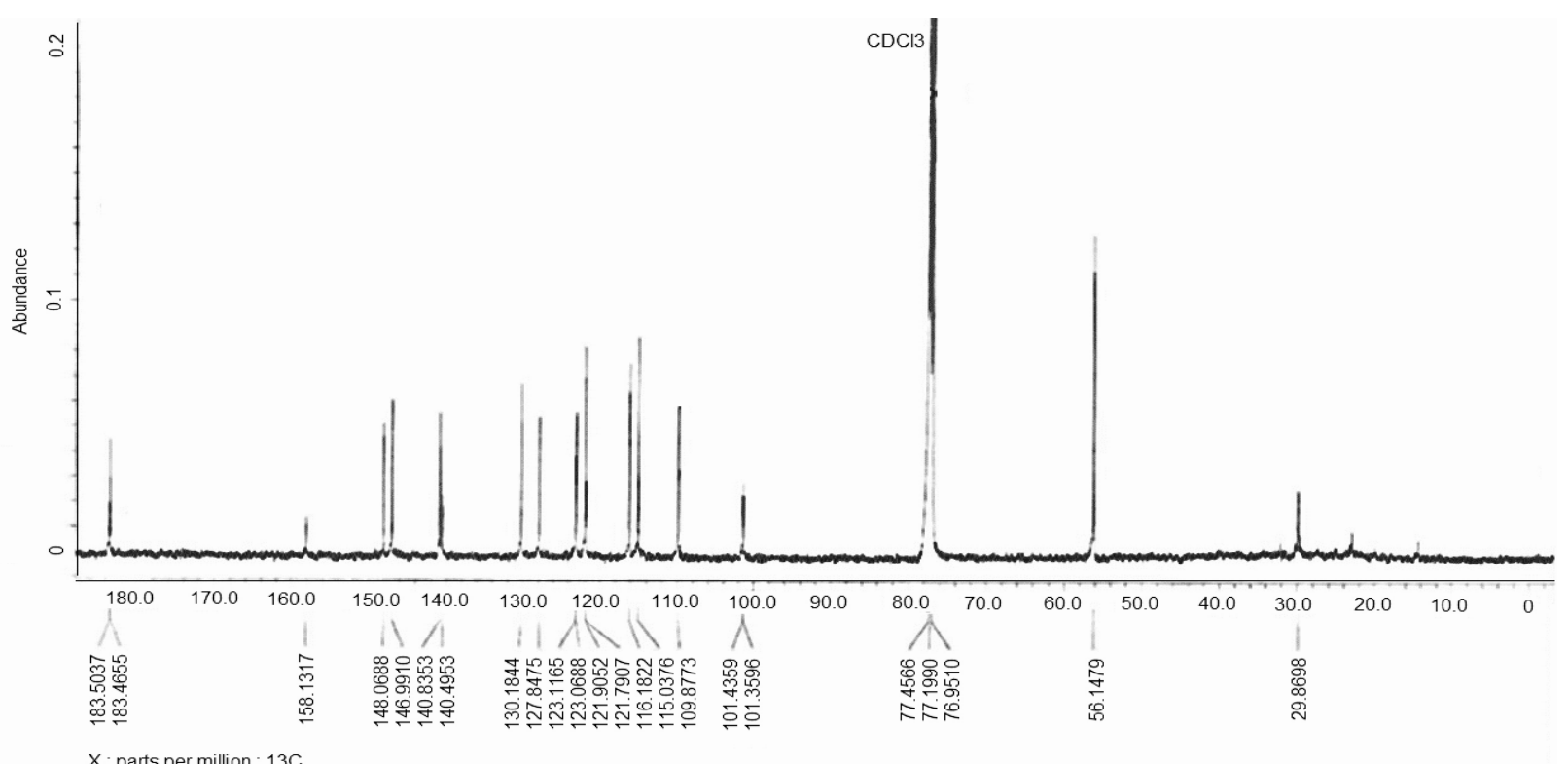

Figure 4. ${ }^{13} \mathrm{C}$ NMR spectrum of compound isolate 1 (in $\mathrm{CDCl}_{3}$ ) fraction chloroform of $\mathrm{C}$. xanthorrhiza 


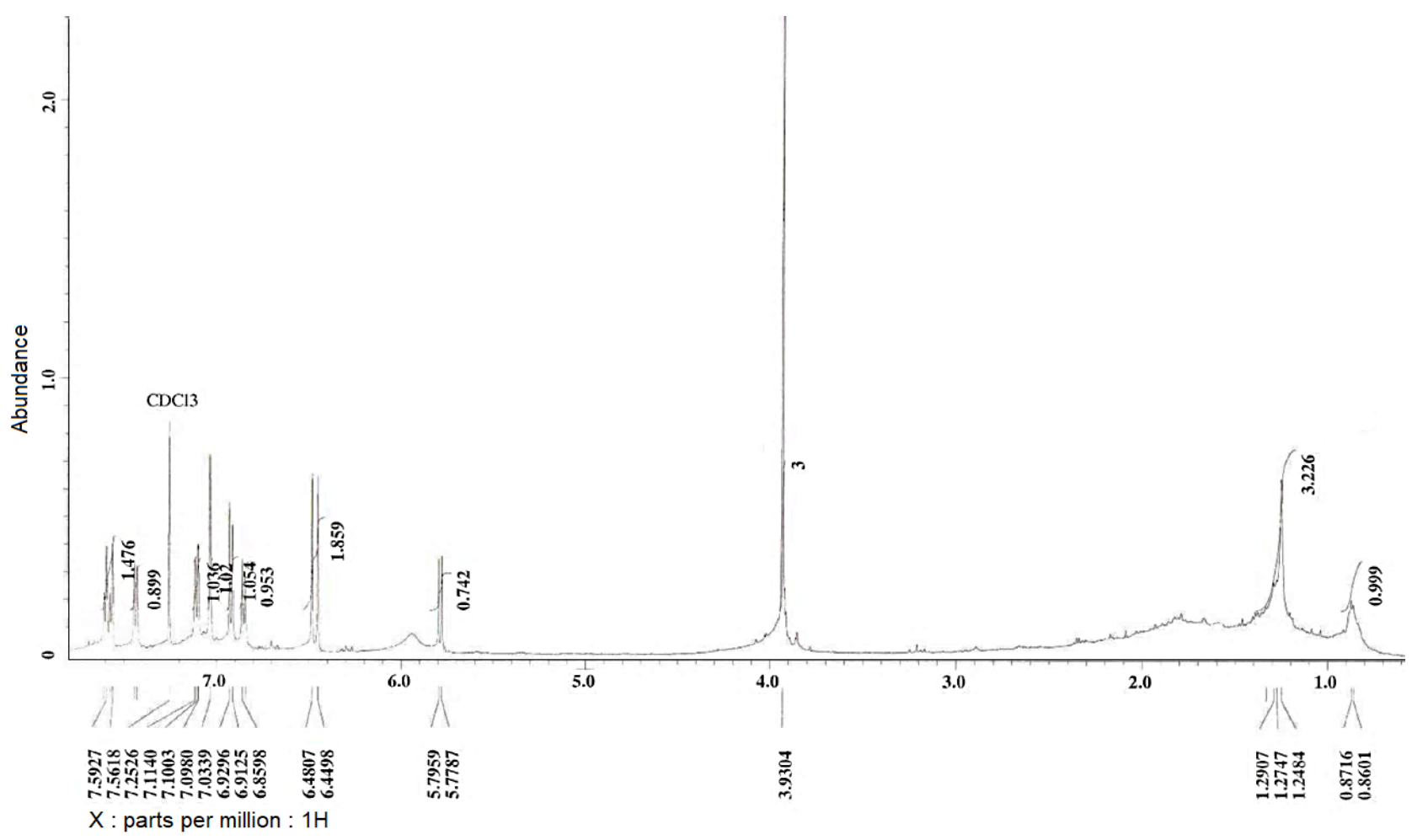

Figure 5. ' $\mathrm{H}$ NMR spectrum of compound isolate 1 (in $\mathrm{CDCl}_{3}$ ) fraction chloroform of $\mathrm{C}$. xanthorrhiza

Table 1. ${ }^{1} \mathrm{H}$ NMR and ${ }^{13} \mathrm{C}$ NMR analysis of one and two dimensional compound isolates 1

\begin{tabular}{clll}
\hline No & $\delta \mathrm{H}(\Sigma \mathrm{H} ; \mathrm{m} ; \mathrm{J} \mathrm{Hz}) \mathrm{ppm}$ & $\delta \mathrm{C} \mathrm{ppm}$ & $\mathrm{HMBC}$ \\
\hline 1 & $1.27(2 \mathrm{H}, \mathrm{s})$ & 29.86 & $\mathrm{C} 3$ \\
2 & & 183.5 & \\
3 & $6.48(1 \mathrm{H}, \mathrm{d}, 15.45)$ & 121.46 & $\mathrm{C} 4 ; \mathrm{C} 1$ \\
4 & $7.59(1 \mathrm{H}, \mathrm{d}, 15.45)$ & 140.49 & $\mathrm{C} 5 ; \mathrm{C} 3$ \\
5 & & 127.8 & \\
6 & $7.11(1 \mathrm{H}, \mathrm{dd}, 1.15: 6.85)$ & 123.1 & $\mathrm{C} 7 ; \mathrm{C} 5$ \\
7 & $6.93(1 \mathrm{H}, \mathrm{d}, 6.85)$ & 115.04 & $\mathrm{C} 5 ; \mathrm{C} 8 ; \mathrm{C} 6$ \\
8 & - & 148.07 & \\
$(\mathrm{OH})$ & & - & \\
9 & - & 146.9 & \\
$\mathrm{OCH}_{3}$ & $3.95(3 \mathrm{H}, \mathrm{s})$ & 56.14 & \\
10 & $7.03(\mathrm{br} \mathrm{s})$ & 109.8 & $\mathrm{C} 9 ; \mathrm{C} 5 ; \mathrm{C} 6 ; \mathrm{C} 4$ \\
$2^{\prime}$ & - & 183.46 & \\
$3^{\prime}$ & $6.49(1 \mathrm{H}, \mathrm{d}, 15.45)$ & 121.48 & $\mathrm{C} 1 ; \mathrm{C} 4^{\prime}$ \\
$4^{\prime}$ & $7.57(1 \mathrm{H}, \mathrm{d}, 15.45)$ & 140.83 & $\mathrm{C}^{\prime} ; \mathrm{C} 5$ \\
$5^{\prime}$ & - & 127.84 & \\
$6^{\prime}$ & $7.44(1 \mathrm{H}, \mathrm{d}, 8.0)$ & 130.18 & $\mathrm{C} 5^{\prime} ; \mathrm{C} 7^{\prime}$ \\
$7^{\prime}$ & $6.85(1 \mathrm{H}, \mathrm{d}, 8.0)$ & 115.04 & $\mathrm{C}^{\prime} ; \mathrm{C} 6^{\prime}$ \\
$8^{\prime}$ & & 158.13 & \\
$(\mathrm{OH})$ & & & \\
$9^{\prime}$ & $6.85(1 \mathrm{H}, \mathrm{d}, 8.0)$ & 115.04 & $\mathrm{C}^{\prime}$ \\
$10^{\prime}$ & $7.44(1 \mathrm{H}, \mathrm{d}, 8.0)$ & 130.18 & \\
\hline
\end{tabular}<smiles>COc1cc(/C=C/C(=O)C(C)C=O)ccc1O</smiles>

Figure 6. Structure of isolate 1 (demethoxycurcumin) 
The spectroscopic data show that isolate 1 is demethoxycurcumin which is a major compound often found in the genus of the Curcuma plant. The NMR spectroscopy data of isolate 1 have high similarity with demethoxycurcumin compound (Kita, Imai, Sawada, Kumagai, \& Seto, 2008). The structure of compound isolate 1 is as in Figure 6. This compound can be isolated in sufficient quantities, so that it is subsequently used as a standard compound for the qualitative and quantitative analysis of total chloroform fractions. To determine of demethoxycurcumin (isolate1) contained in the chloroform fraction, an analysis was carried out using
TLC Scanner with chloroform solvent and using isolate 1 (demethoxycurcumin) as a standard. The results of the thin layer chromatogram are shown in Figure 7.

TLC results showed that $R_{f}$ of demethoxycurcumin 0.14 , so that stains from chloroform fraction in the area were considered $R_{f}$ with demethoxycurcumin. The results of the TLC scanner chromatogram showed the content of as much as $20.97 \%$. The TLC scanner chromatogram data is shown in Figure 8. Curcuminoid found in some Curcuma rhizomes differ depending on the type of species. Curcuminoid from C. xanthorrhiza consists of curcumin and demethoxycurcumin (Lechtenberg, 2004).

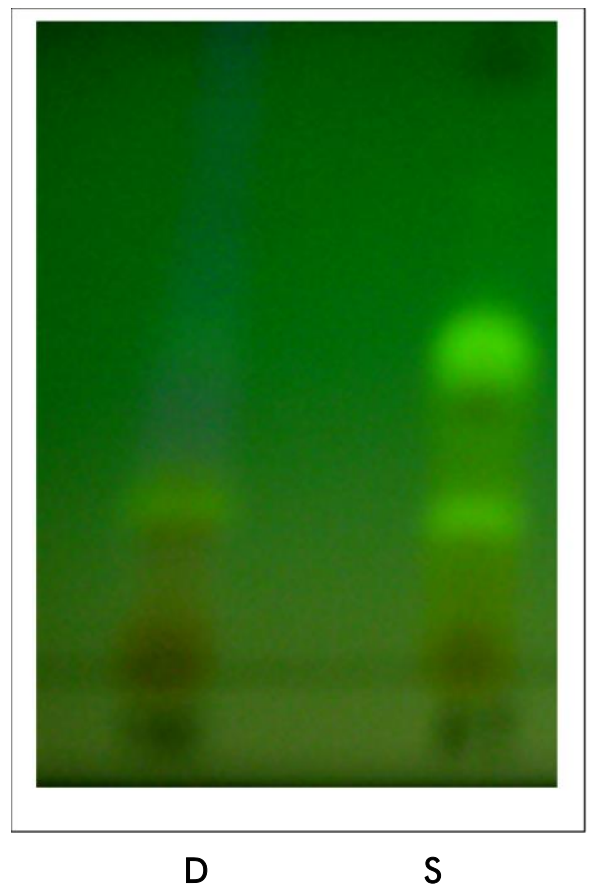

Figure 7. Thin layer chromatogram (TLC) of isolate 1 (demethoxycurcumin =D) and chloroform fraction from C. xanthorrhiza (S)

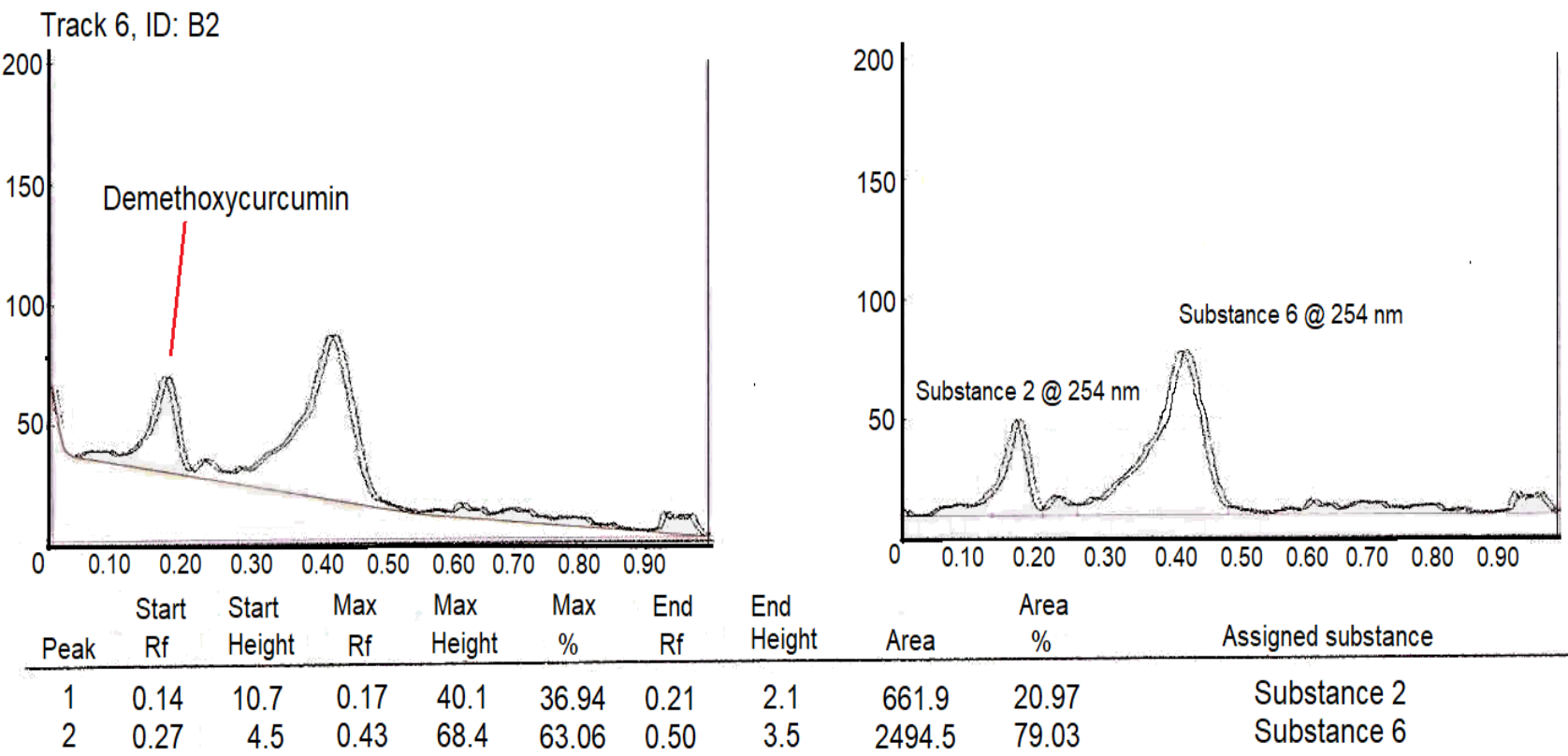

Figure 8. TLC Scanner data from chloroform fraction from C. xanthorrhiza 
Table 2. Data of antioxidant activity

\begin{tabular}{llllc}
\hline Sample & \multicolumn{5}{c}{ Data of calculated antioxidant activity } \\
\hline & $\begin{array}{c}\text { Consentration } \\
(\mu \mathrm{g} / \mathrm{mL})\end{array}$ & $\begin{array}{l}\text { Inhibition } \\
\text { activity }(\%)\end{array}$ & Regression equation & $\begin{array}{c}\text { Antioxidant } \\
\text { activity } \\
\left(\mathrm{IC}_{50} \mu \mathrm{g} / \mathrm{mL}\right)\end{array}$ \\
\hline Chloroform & 50 & 75.41 & $\mathrm{y}=1.0778 \mathrm{x}+23.099$ & \\
fraction of C. & 25 & 52.96 & $\mathrm{R}^{2}=0.9774$ & 24.98 \\
xanthorrhiza & 12.5 & 36.69 & & \\
& 6.25 & 32.78 & & 1.27 \\
\hline Ascorbic acid & 3.125 & 22.07 & & \\
(positive & 5.00 & 95.59 & $\mathrm{y}=13.76 \mathrm{x}+32.51$ & \\
control) & 2.50 & 79.82 & $\mathrm{R}^{2}=0.883$ & \\
& 1.25 & 51.45 & & \\
\hline
\end{tabular}

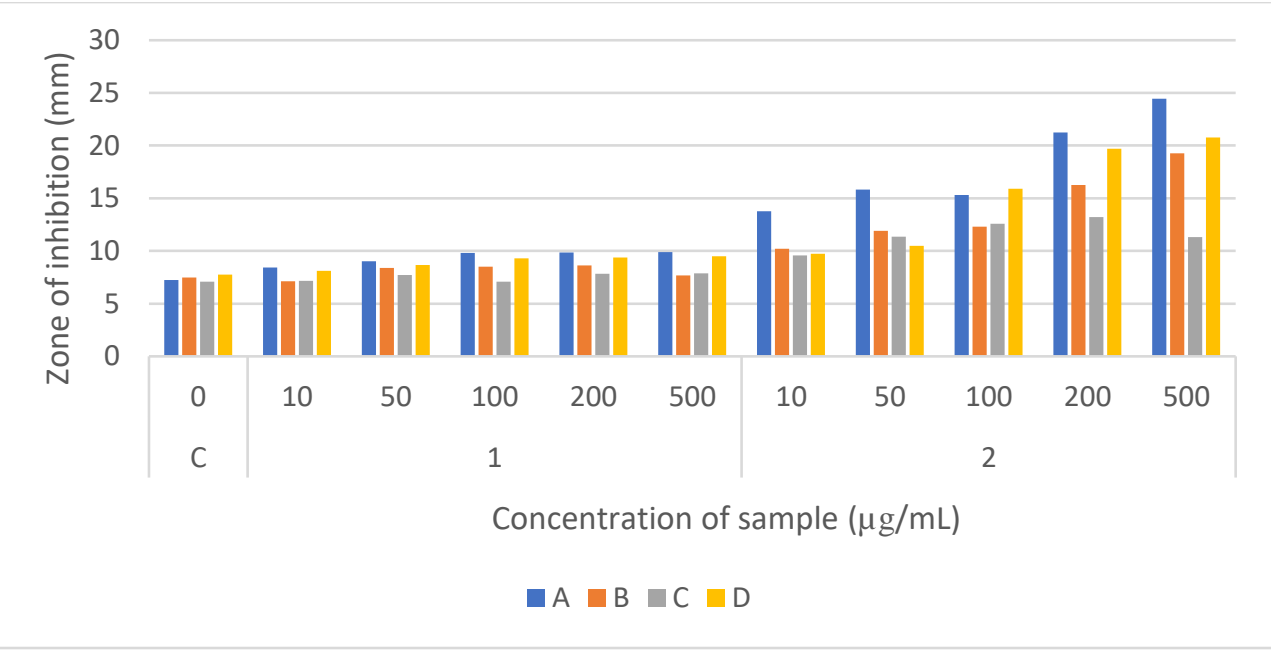

$\mathrm{A}=$ Escherichia coli ATCC 11229; B=Staphylococcus aureus ATCC 25923; C= Streptococcus mutans; $\mathrm{D}=$ Staphylococcus epidermidis FNCC 0048; $\mathrm{C}=\mathrm{DMSO} ; 1=$ curcuminoid extract; 2 = cloramphenicol

Figure 5. Antibacterial activity of curcuminoid and chloramphenicol (positve control)

The chloroform fraction from this experiment was tested for its activity as an antioxidant. As a radical source, DPPH is used. The inhibition activity was calculated based on the reduction in sample absorption compared to the blank measured at the wavelength of $516 \mathrm{~nm}$. Ascorbic acid is used as a positive control. Data of antioxidant activity are found in Table 2.

The phenolic compounds of chloroform fraction consist of demethylcurcumin $(20.97 \%)$ and other phenolic compounds not determined in this study. Phenolic compounds generally show high antioxidant activity. Antioxidant activity of chloroform fraction showed with $\mathrm{IC}_{50} 24.98 \mu \mathrm{g} / \mathrm{mL}$. However, its activity is still relatively lower when compared with ascorbic acid which shows $I_{50} 1.27 \mu \mathrm{g} / \mathrm{mL}$. Phenolic levels extracted from plant samples are also determined by the type of solvent used to extract this compound (Nisar et al, 2015; Ereifej, et al, 2016). The total phenolic content in methanolic extracts of rhizome $C$. aeruginosa, C. malabarica, C. rakthakanta and C. sylvatica ranged from 210 to $700 \mathrm{mg}$ gallic acid equivalents $/ 100 \mathrm{~g}$ and shows high activity as antioxidant (Angel, Vimala, \& Nambisan, 2016). Several studies show that many secondary metabolites derived from plants are antioxidants, especially phenolic compounds such as flavonoid and polyphenol. Demethoxycurcumin in chloroform fraction from C. xanthorrhiza besides having phenol groups also has conjugated double bonds. The double bond is also easy to capture radicals, so it has a very active antioxidant activity $\left(\mathrm{IC}_{50}<30 \mu \mathrm{g} / \mathrm{mL}\right)$.

Antibacterial activity test using Kirbi-Baver diffusion method, using four pathogenic bacteria, namely $S$. aureus ATCC 25923, E. coli ATCC 11229 , S. mutans, and S. epidermidis FNCC 0048. Activity test as antibacterial can be seen at Figure 5. Observation of inhibitory zones that showed inhibition of bacteria was carried out at the $6^{\text {th }}, 12^{\text {th }}, 18^{\text {th }}$ and $24^{\text {th }}$ hours. However, the optimal data for four bacteria was at $12^{\text {th }}$ observation. Some bacteria showed a decrease in activity at the $18^{\text {th }}$ observation, and some bacteria died 
at $24^{\text {th }}$ hours. Observation of activity at $12^{\text {th }}$ hours was also based on observations of bacterial growth curves which showed that at $12^{\text {th }}$ hours the four bacteria were in the logarithmic phase which indicated that the four bacteria were in optimal growth period. The effectiveness of antibacterial activity can be seen from the inhibition zone formed.

According to the classification of responses to bacterial growth barriers seen based on the diameter of the clear zone consists of 4 groups, namely weak responses (diameter $\leq 5 \mathrm{~mm})$, medium $(5-10 \mathrm{~mm}$ diameter), strong (diameter 10-20 mm), and very strong ( $\geq 20 \mathrm{~mm}$ in diameter) (Davis \& Stout, 1971). From the data shows (Figure 5) that 10\% DMSO used as sample solvent also shows inhibitory activity. However, the activity of curcuminoid fraction from $\mathrm{C}$. xanthorrhiza at concentrations of more than $10 \mu \mathrm{g} / \mathrm{ml}$ showed more higher activity than DMSO. The curcuminoid fraction used in various concentration of $10 ; 50 ; 100 ; 250$; and $500 \mu \mathrm{g} / \mathrm{mL}$. From this graph, the activity of curcuminoid fraction against $E$. coli and S. epidermidis bacteria is directly proportional to the increase in concentration. Optimal activity at a concentration of $500 \mu \mathrm{g} / \mathrm{mL}$. S. aureus showed optimal activity at a concentration of $100 \mu \mathrm{g} / \mathrm{mL}$, whereas S. mutans showed optimal activity at a concentration of $200 \mu \mathrm{g} / \mathrm{mL}$. However, the research data shows that the activity of the curcuminoid fraction against all bacteria used is classified as moderate. As a positive control, chloramphenicol is an antibiotic commonly used in some anti-infectious drugs showing high activity against all bacteria used.

Several previous studies showed a variety of antibacterial activity from Curcuma rhizome extract depending on species, type of bacteria used, and solvents used for extraction. Research on extracts of $C$. longa and $A$. galanga showed weak activity against $S$. aureus and against S. Typhi (Khattaka, Rehmana, \& Shahb, 2005). Research on acetone extract and the $n$-hexane fraction exhibited significant activities against Bacillus subtilis, Pseudomonas aeruginosa, and Staphylococcus aureus, and weak activities against Shigella dysenteriae and Vibrio cholerae. The extract showed inactive against Escherichia coli, Enterobacter aerogenes and Salmonella thypi, while the chloroform fraction was devoid of activities (Diastuti, Syah, Juliawaty, \& Singgih, 2014). Xanthorrhizol isolated from the ethanol extract of Curcuma xanthorrhiza is a sesquiterpene compound showed strongly antibacterial activity with thermal and $\mathrm{pH}$ stability (Lee, Shim, Rukayadi, \& Hwang, 2008).

Xanthorrhizol exhibited the highest antibacterial activity against Streptococcus species causing dental caries and also demonstrated antibacterial potential against $A$. viscosus and $P$. gingivalis which are responsible for periodontitis (Hwang, Shim, \& Pyun, 2000). The previous studies showed curcumin can kill gram-positive and negative bacteria by damaging the membrane (Tyagi, Singh, Kumari, Kumari, \& Mukhopadhyay, 2015). Curcuminoid extract from this study did not contain terpenoid compounds such as xanthorrizol, but only contained phenolic compounds such as curcumin and demethoxycurcumin. The results showed that curcuminoid extract had moderate activity against pathogenic bacteria E. coli ATCC 11229, S. aureus ATCC 25923, S. mutans, and S. epidermidis FNCC 0048 used in this study.

Curcuminoid extract contains phenolic compounds which in addition to showing antioxidant activity can also damage bacterial cell walls, so that the main components of the cells come out and cause bacterial cell death, and inhibit cell protein formation. Several previous studies have shown that natural phenol compounds play many important roles in human health as evidenced by their antibacterial, antifungals, antioxidants, and anti-cancer activities (Panche, Diwan, \& Chandra, 2016). Thus, the results of this study can be used for further research on the potential of curcuminoid form C. zanthorrhiza as an antioxidant and natural antibiotic.

\section{CONCLUSIONS}

The results showed that the chloroform fraction yield was $10.06 \%$ with demethylcurcumin content of $20.97 \%$. The total phenolic content of the chloroform fraction was $745.45 \pm 18.5 \mathrm{mg} \mathrm{GA} / \mathrm{g}$ extract. The antioxidant activity of chloroform fraction showed very active activity with $\mathrm{IC}_{50} 24.98 \mu \mathrm{g} / \mathrm{mL}$. Antibacterial activity of the four pathogenic bacterial showed medium activity.

\section{ACKNOWLEDGMENTS}

This research was funded by Research group grant of DIPA Universitas Negeri Yogyakarta 2018. The author is very grateful for the research grant.

\section{REFERENCES}

Angel, G. R., Vimala, B. \& Nambisan, B. (2012). Phenolic content and antioxidant activity in five underutilized starchy Curcuma species. International Journal of Pharmacognosy and Phytochemical 4(2), 69-73.

Amalrai, A, Pius, A, Gopi, S. \& Gopi S. J. (2017). Biological activities of curcuminoids, other biomolecules from turmeric and their derivatives e A review. Journal of Traditional and Complementary Medicine 7 (2017) $205 e 233$.

Bishnu, P.M, Pankai, B, Pratibha, A, Kashi, R.G, Sanjiv, N. \& Nabara, D. (2015). Evaluation of antibacterial activity of some traditionally used medicinal plants against human pathogenic bacteria. BioMed Research International 2015,1-6.

Cronquist, A. (1981). An integrated system of classification of flowering plants, New York: Columbia In Press; $316-318$. 
Cucuzza, L.S, Motta, M.L, Miretti, S, Accornero, P, \& Baratta, M. (2008). Curcuminoid phospholipid complex induces apoptosis in mammary epithelial cells by STAT-3 signaling. Experimental \& Molecular Medicine 40, 64757.

Davis, W.W. \& Stout, T.R. (1971). Disc plate method of microbiological antibiotic assay. American Society for Microbiology 22(4), 659-665.

Diastuti, H, Syah, Y.M, Juliawaty, L.D. \& Singgih, $M$. (2014). Antibacterial Curcuma xanthorrhiza extract and fractions. Journal Mathemathical and Fundamental Science 46 (3), 224-234. DOI:

http://dx.doi.org/10.5614\%2Fi.math.fund.sci. 2014.46.3.2

Ereifej, K, Feng, H, Rababah, T.M, Tashtoush, S.H, AlU'datt, M. H, Gammoh, S. \& Al-Rabadi, G.J (2016). Effect of extractant and temperature on phenolic compounds and antioxidant activity of selected spices. Food and Nutrition Sciences 7, 362-370.

Gunes, H, Gulen, D, Mutlu, R, Gumus, A, Tas,, \& Topkaya, A.E. (2016). Antibacterial effects of curcumin: An in vitro minimum inhibitory concentration study, Toxicology and Industrial Health 32(2), 246-250. DOI: $10.1177 / 0748233713498458$

Hagerman, A, Harvey, M.I, Makkar, A.H, Mueller, I. H, \& Makar, H.P.S. (2000). Quantification of tannins in tree foliage - a laboratory manual; Viena: FAO/IAEA.

Hanumantharaju, N, Shashidhara, S, Rajasekharan, P. E, \& Rajendra, C.E. (2010). Comparative evaluation of antimicrobial and antioxidant activities of Kaempferia galanga for natural and micropropagated plant. International Journal of Pharmacy and Pharmaceutical Sciences 2(4), 72-5.

Heyne K. (1987). Tumbuhan Berguna Indonesia. 3th ed. Jakarta: Balitbang Kehutanan;1390-443.

Hwang, J.K, Shim, J.S, \& Pyun,Y.R, (2000). Antibacterial activity of xanthorrhizol from Curcuma xanthorrhiza against oral pathogens. Fitoterapia 71, 321-323.

Itokawa, H, Qian ,S, Akiyama ,T, Susan, L, \& Lee, K.S. (2008). Review recent advances in the investigation of curcuminoids. Chinese Medicine 3, 1-13.
Khattak, S, Rehman, S, Shah, U.H, Ahmad,W.W. \& Ahmad, M.(2005). Biological effects of indigenous medicinal plants Curcuma longa and Alpinia galanga. Fitoterapia 76, 254-7.

Kita, T, Imai, S, Sawada, H, Kumagai, H, \& Seto, H. (2008). The biosynthetic pathway of curcuminoid in turmeric (Curcuma longa) as revealed by ${ }^{13} \mathrm{C}$-labeled precursors. Bioscience, Biotechnology, and Biochemistry 72 (7), 17891798.

Lee, L.Y, Shim, J.S, Rukayadi,Y, \& Hwang, J.K. (2008). Antibacterial activity of xanthorrhizol isolated from Curcuma xanthorrhiza Roxb. against foodborne pathogens. Journal of food protection 71(9), 1926-30.

Lechtenberg, M, Quandt, B. \& Nahrstedt, A. (2004). Quantitative determination of curcuminoids in Curcuma rhizomes and rapid differentiation of Curcuma domestica Val. and Curcuma xanthorrhiza Roxb. By capillary electrophoresis. Phytochemical Analysis. 15, 152- 158.

Mun, S.H, Joung, D.K, Kim, Y.S, Kang, O.H, Kim, S.B. \& Seo, Y.S, et al. (2013). Synergistic antibacterial effect of curcumin against methicillin-resistant Staphylococcus aureus. Phytomedicine. 20(8-9), 714-718.

Nisar, T, lqbal, M, Raza, A, Madiha, Safdar, Iftikhar, F. \& Waheed, M. (2015). Estimation of total phenolics and free radical scavenging of turmeric (Curcuma longa). American-Eurasian Journal of Agricultural \& Environmental Sciences $15(7), 1272-1277$.

Nurfina, A. \& Atun, S. (2016). Pharmacological test of herbal products from temulawak (Curcuma Xanthorhiza) as antihypercholesterol by in vivo. International Journal of Pharmaceutical Sciences and Research 8, 807-11.

Panche, A.N, Diwan, A.D, \& Chandra, S.R. (2016). Flavonoids: an overview. Journal of Nutritional Science 5(e47), 1-15.

Tyagi, P, Singh, M, Kumari, H, Kumari, A. \& Mukhopadhyay, K. (2015). Bactericidal activity of curcumin is associated with damaging of bacterial membrane. PLoS ONE 10(3), e0121313.doi:10.1371

Wrigh, L.E, Frye, J.B., Gorti, B, Timmermann, B.N, \& Funk, J.L. (2013). Bioactivity of turmericderived curcuminoids and related metabolites in breast cancer. Current Pharmaceutical Design 19(34): 6218-6225. 